\title{
Remote Control Berbasis Internet of Things ( IoT)
}

\section{(Remote Control Based On Internet of Things)}

\author{
Hafiz Mukhsin $^{1 *}$, Bekti Yulianti ${ }^{2}$ \\ ${ }^{1,2}$ Program Studi Teknik Elektro, Universitas Dirgantara Marsekal Suryadarma \\ E-mail : hafizmukhsin1@gmail.com,byulianti@unsurya.ac.id
}

\begin{abstract}
Most electronic devices nowadays are equipped with a remote control so that users can activate and control the equipment from a certain distance. The problem that arises is that each electronic device has a different remote control. This becomes impractical if at home there are many electronic equipment. The remote control design uses the TUYA application in this paper and is integrated with a smart system to run automation commands and the "one push" feature that works to control these electronic devices. In addition, this remote control is also designed based on the GPS point or coordinates of the user's smartphone, if the user leaves the location point, the electronic device will turn off and vice versa. To save power usage and also efficiency, the tool is set to automation where the electronic device will turn off and on according to a predetermined time. Based on trials, all electronic equipment runs if the connectivity is stable, does not require a lot of quota and the connection is fast. The distance between the remote and the router is 29.79 meters with a free space loss of $2.295 \mathrm{~dB} / \mathrm{km}$.
\end{abstract}

Keywords - Remote Control, TUYA, Infrared, Smart system, One Push

Abstrak - Sebagian besar perangkat elektronik pada saat ini dilengkapi dengan remote control sehingga pengguna dapat mengaktifkan dan mengontrol peralatan tersebut dari jarak tertentu. Permasalahan yang timbul setiap peralatan elektronik memiliki remote control yang berbeda. Ini menjadi tidak praktis apabila di rumah terdapat banyak peralatan elektronik. Perancangan remote control menggunakan aplikasi TUYA pada tulisan ini dan diintegrasikan smart system untuk menjalankan perintah otomatisasi dan fitur "one push" yang bekerja untuk mengendalikan perangkat elektronik tersebut. Selain itu pada remote control ini juga rancang berdasarkan titik GPS atau koordinat dari smartphone pengguna, jika pengguna meninggalkan titik lokasi maka alat electronik akan mati begitu pula sebaliknya. Untuk menghemat penggunaan daya dan juga effisiensi pada alat disetting otomatisasi dimana alat elektronik akan mati dan menyala sesuai waktu yang telah ditentukan. Berdasarkan uji coba semua peralatan elektronik berjalan jika konektifitas stabil, tidak memerlukan kuota yang banyak dan koneksi cepat. Jarak jangkauan antara remote dan router yaitu 29,79 Meter dengan free space lose sebesar 2,295 dB/km.

Kata Kunci - Remote Control, TUYA, Infrared, Smart system, One Push

\section{PEndahuluan}

$\mathrm{R}$ emote control adalah suatu alat elektronik yang digunakan untuk mengoperasikan suatu perangkat dari jarak tertentu. Penggunaan remote control untuk mengendalikan peralatan dapat mempermudah pekerjaan manusia, tetapi menjadi tidak efisien apabila perangkat yang dimiliki banyak dan setiap perangkat tersebut memiliki remote control yang berbeda-beda. Selain itu ketergantungan pada sumber daya berupa baterai menjadi peran utama untuk menyalakan remote tersebut.

*Penulis Korespondensi (Hafiz Mukhsin)

E-mail: Hafizmukhsin1@gmail.com 
Remote control adalah suatu alat elektronik yang digunakan untuk mengoperasikan suatu perangkat dari jarak tertentu. Penggunaan remote control untuk mengendalikan peralatan dapat mempermudah pekerjaan manusia, tetapi menjadi tidak efisien apabila perangkat yang dimiliki banyak dan setiap perangkat tersebut memiliki remote control yang berbeda-beda. Selain itu ketergantungan pada sumber daya berupa baterai menjadi peran utama untuk menyalakan remote tersebut.

Selama ini remote control yang digunakan berbasis Infra Red atau remote saklar yang melalui kabel, tetapi pengendalian tersebut dibatasi oleh jarak jangkauan. Salah satu solusi untuk memecahkan masalah tersebut adalah ponsel berbasi android sebagai pengganti remote control. Android merupakan sebuah sistem operasi pada ponsel berbasis Linux yang mencakup sistem operasi dan middleware. Fasilitas opensource pada platform android memungkinkan pemakai mengembangkan inovasi-inovasi yang berbasis internet.

Atas dasar uraian tersebut, dilakukan pengembangan alat yang befungsi sebagai remote control untuk mengendalikan seluruh peralatan elektronik pada ruang / lokasi yang sama dengan menggunakan sebuah smartphone. Alat ini dapat pula dikendalikan dari luar kota ataupun luar negeri dan juga bisa beroperasi sesuai lokasi berdasarkan titik koordinat dari Global Positioning System (GPS).

\section{LANDASAN TEORI}

\section{A. Internet Of Things (IoT)}

IoT (Internet of Thing) dapat didefinisikan kemampuan berbagai divice yang bisa saling terhubung dan saling bertukar data melelui jaringan internet. IoT merupakan sebuah teknologi yang memungkinkan adanya sebuah pengendalian, komunikasi, kerjasama dengan berbagai perangkat keras, data melalui jaringan internet. Sehingga bisa dikatakan bahwa Internet of Things (IoT) adalah ketika kita menyambungkan sesuatu (things) yang tidak dioperasikan oleh manusia, ke internet[1].

Namun IOT tidak hanya berkaitan dengan pengendalian perangkat melalui jarak jauh, tapi juga bagaimana suatu sistem berbagi data, memvirtualisasikan segala hal nyata ke dalam bentuk internet, dan lain-lain. Internet menjadi sebuah penghubung antara sesama mesin secara otomatis. Selain itu juga adanya user yang bertugas sebagai pengatur dan pengawas bekerjanya alat tersebut secara langsung. Manfaatnya menggunakan teknologi IoT yaitu pekerjaan yang dilakukan oleh manusia menjadi lebih cepat, muda dan efisien .

Model arsitektur Internet of Things terbagi menjadi 3 lapisan utama yaitu :

1. Layer 1 terdiri dari grup perangkat keras (hardware).

Pada layer 1 terdiri dari constrain device yaitu perangkat yang memiliki fitur terbatas bergantung pada perangkat lain untuk melakukan beberapa proses dan unconstrain device yaitu perangkat yang memiliki cukup fitur yang diperlukan untuk menjalankan proses.

2. Layer 2 terdiri dari grup perangkat lunak (software).

Layer ini berfungsi untuk menyediakan mekanisme dan fungsional perangkat keras seperti sensor, actuator, penanganan proses dan lain-lain.

3. Layer 3 adalah pengguna (user).

Layer ini merupakan merupaka klien yang memanfaatkan layanan yang disediakan oleh lapisan perangkat lunak.

Pada constrain device terhubung dengan perangkat eksternal yaitu smart gateway yang memiliki threat untuk mengekspos fungsionalitas kepada client. Sedangkan pada unconstrain device memiliki komponen middleware yang menyediakan fungsionalitas langsung ke client melalui platform atau layanan cloud pihak ketiga. 


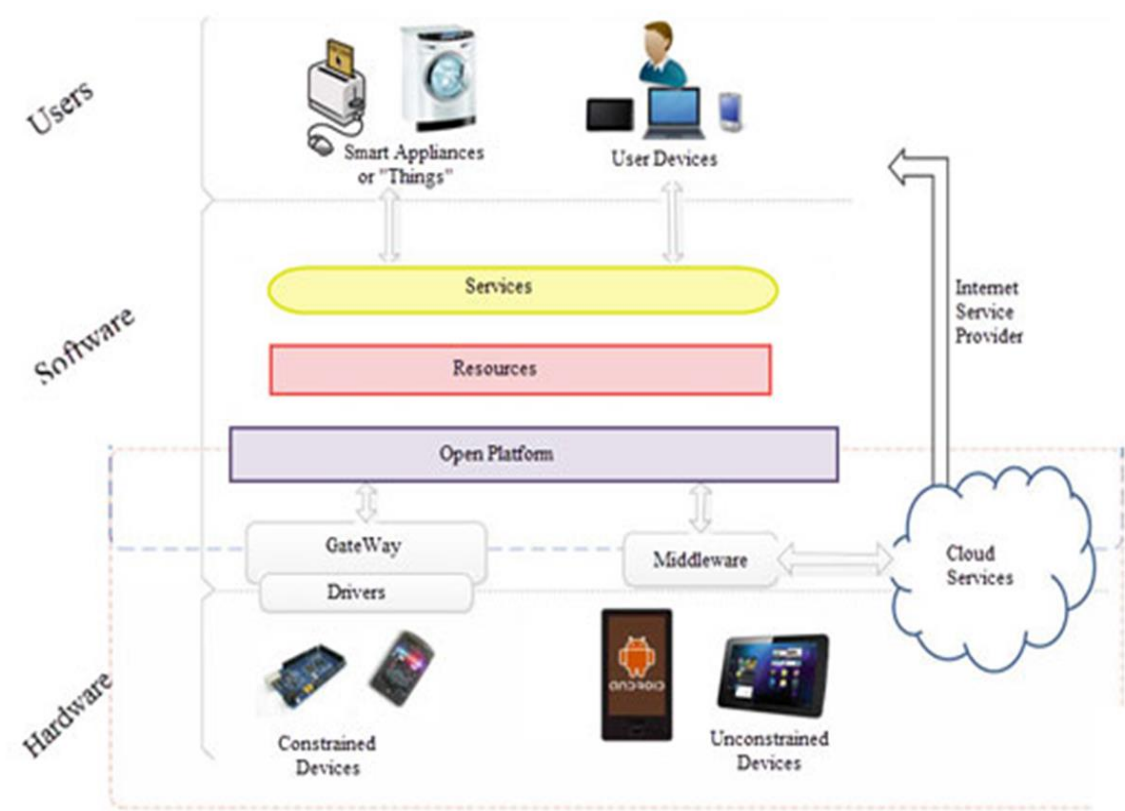

Gambar 1. Arsitektur IoT

\section{B. TUYA}

TUYA merupakan platform pintar global, platform pengembangan 'AI+IoT' dan platform interaksi suara AI terkemuka. Tuya menyediakan solusi lengkap bagi pengguna yang mencakup akses perangkat keras, service cloud, dan kapabilitas pengembangan aplikasi.

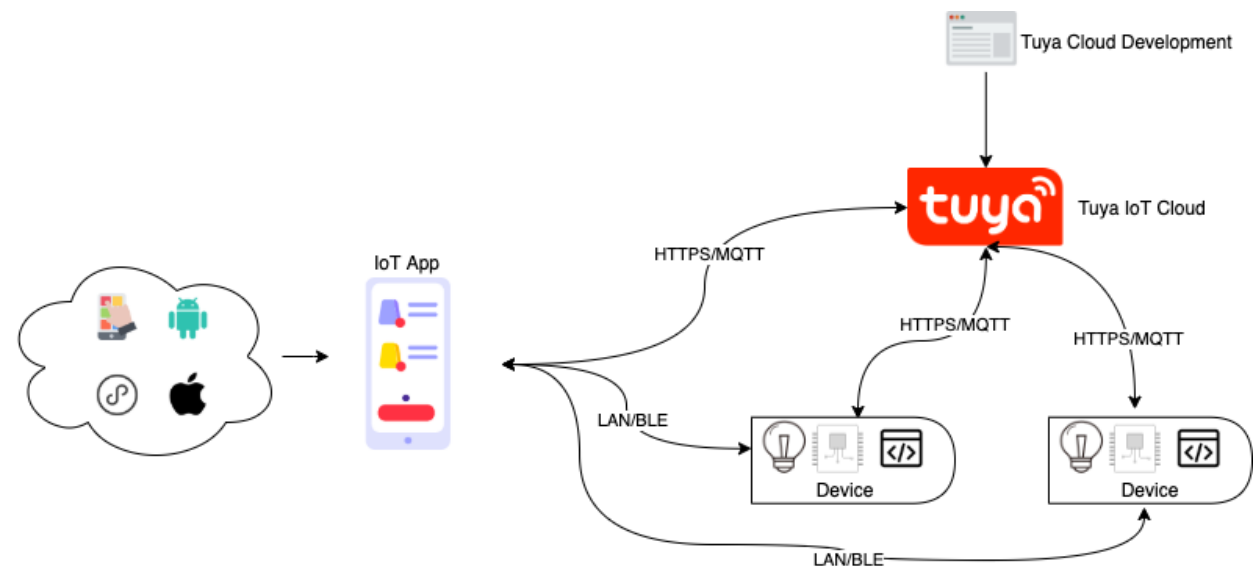

Gambar 2. TUYA Working

Data yang dikirimkan oleh perangkat dan aplikasi yang terhubung akan ditampilkan di Platform Tuya IoT dengan berbagai metode statistik setelah desensitisasi dan enkripsi sesuai dengan peraturan keamanan. Sesuai dengan kebutuhan analisis aktual, platform menyediakan berbagai metode dan alat statistik, seperti statistik berdasarkan waktu atau wilayah tertentu, atau perbandingan statistik berdasarkan jumlah atau persentase. Selain dashboard, personel pemrosesan data dapat mengunduh materi data mentah untuk analisis mendalam guna memenuhi kebutuhan yang dipersonalisasi.

Dengan layanan manajemen perangkat, pengembang dan teknisi operasi dapat memantau semua perangkat yang terhubung ke TUYA IoT Cloud, melacak log aktivitas di smartphone android, mengelolanya dari jarak jauh, dan menyediakan pembaruan OTA di seluruh dunia. Saat 
perangkat dalam status prasetel atau melaporkan data tertentu, perangkat dapat mengirim pemberitahuan ke pengguna perangkat dan teknisi operasi untuk penanganan segera.

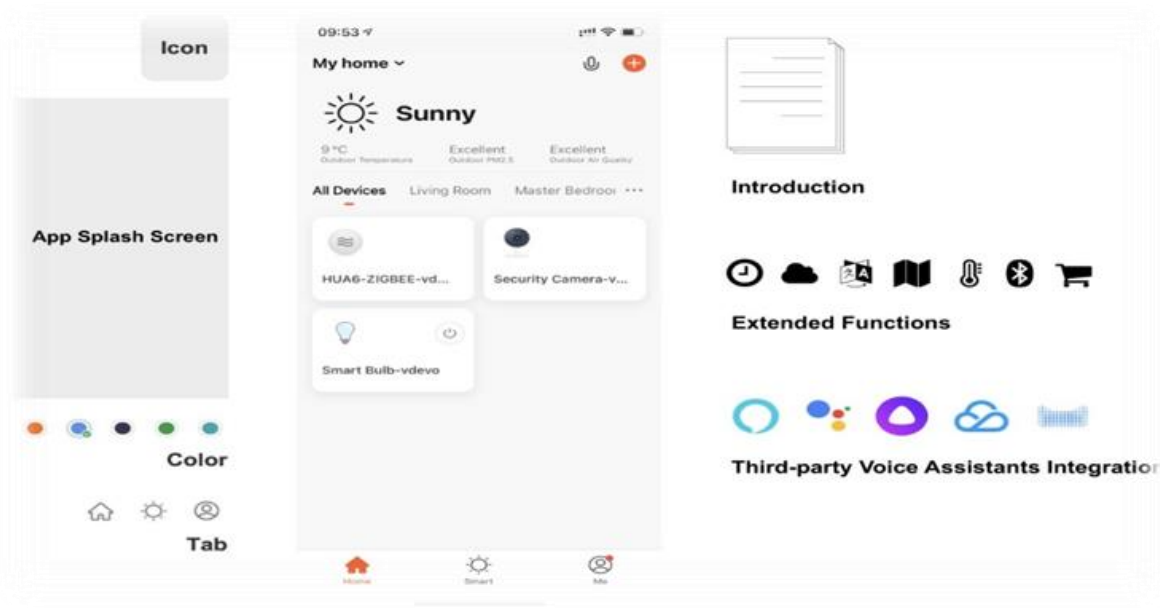

Gambar 3. Aplikasi Smartlife / TUYA

\section{Remote Control Universal}

Remote control adalah sebuah alat yang berfungsi sebagai pengendali jarak jauh dari sebuah perangkat elektronik. Secara umum, ada dua jenis remote control yaitu inframerah (infrared = IR), dan frekuensi radio (radio frequency $=$ RF). Remote control IR bekerja dengan mengirimkan gelombang inframerah ke perangkat elektronik, sementara remote control RF bekerja dengan cara yang sama namun menggunakan gelombang radio.

Solusi remote control frekuensi radio inframerah (IR RF) adalah solusi kontrol cerdas kecil. Solusinya terdiri dari modul Wi-Fi yang sangat terintegrasi, modul Sub-G frekuensi radio, LED IR, dan penerima IR terintegrasi. Pada aplikasi seluler seperti aplikasi TUYA Smart, pengguna dapat mengontrol peralatan rumah tangga dari jarak jauh, seperti AC, TV, dekoder, kipas angin, motor tirai, dan rak pengering. Remote control seperti ini disebut dengan remote control universal. Pada remote control universal ini juga disematkan radio frekuensi sebagai penangkap sinyal jarak jauh. Berikut ini adalah fitur yang terdapat di dalam remote control universal :

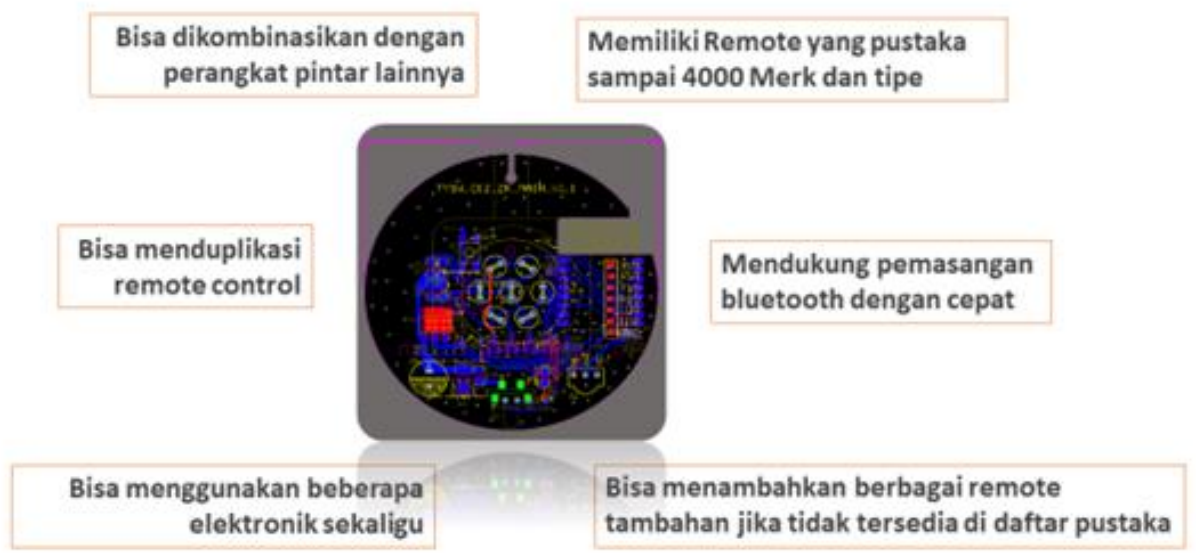

Gambar 4. Fitur Remote Kontrol Universal 


\section{Infra Merah}

Sensor Infrared adalah komponen elektronika yang dapat mendeteksi benda ketika cahaya infra merah terhalangi oleh benda. Sensor infared terdiri dari led infrared sebagai pemancar dan fototransistor sebagai penerima cahaya infra merah. Led infrared sebagai pemancar cahaya infra merah merupakan singkatan dari Light Emitting Diode Infrared yang terbuat dari bahan Galium Arsenida (GaAs) dapat memancarkan cahaya infra merah dan radiasi panas saat diberi energi listrik.

Sinar inframerah merupakan cahaya yang tidak tampak, jika dilihat dengan dengan spektroskop cahaya makaradiasi cahaya inframerah akan nampak pada spektrum elektromagnet denganpanjang gelombang di atas panjang gelombang cahaya merah, dengan panjang gelombang ini maka cahaya infra merah ini akan tidak tampak oleh mata namun radiasi panas yang ditimbulkannya masih terasa/dideteksi. Inframerah dapat dibedakan menjadi tiga daerah yakni:

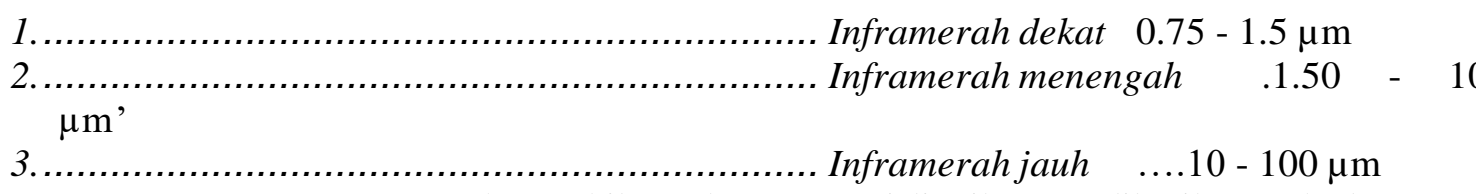

Proses pemancaran cahaya akibat adanya energi listrik yang diberikan terhadap suatu bahan disebut dengan sifat elektroluminesensi. Fototransistor sebagai penerima cahaya infra merah merupakan tranduser yang dapat mengubah energi cahaya infra merah menjadi arus listrik. Fototransistor adalah sebuah penerima cahaya infra merah yang merupakan kombinasi fotodioda dan penguatan transistor. Fototransistor memiliki dengan sensitifitas yang lebih tinggi dibandingkan fotodioda, tetapi dengan waktu respon yang secara umum akan lebih lambat daripada fotodioda.

Ketika cahaya infra merah terhalangi oleh benda, cahaya infra merah tidak diterima oleh basis fototransistor sehingga tidak ada arus listrik pada basis maka basis akan berubah seperti saklar (switch open). Tidak adanya arus pada basis fototransistor karena tidak terjadinya pergerakan elektron dan hole.

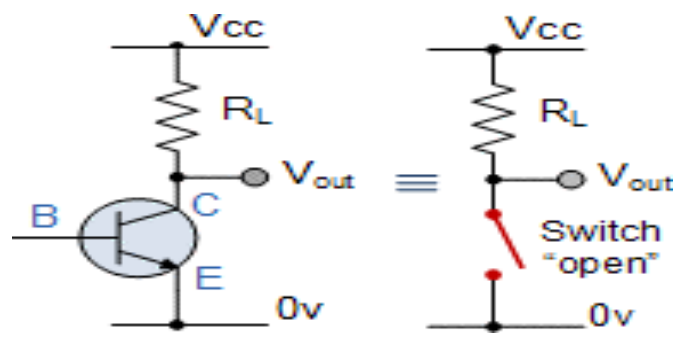

Gambar 5. Keadaan Basis Ketika Cahaya Infra Merah Terhalangi Oleh Benda danBerubah Menjadi Saklar (Switch Open)

\section{E. Modul TYWE3S}

TYWE3S adalah modul Wi-Fi tertanam berdaya rendah yang dikembangkan Tuya. Ini terdiri dari chip RF nirkabel yang sangat terintegrasi (ESP8266), beberapa periferal, tumpukan protokol jaringan Wi-Fi tertanam, dan beragam fungsi perpustakaan.

TYWE3S memiliki CPU 32-bit berdaya rendah yang tertanam, memori flash $2 \mathrm{MB}$, memori akses acak statis (SRAM) $50 \mathrm{~KB}$, dan periferal yang kaya. TYWE3S adalah platform RTOS yang mengintegrasikan semua pustaka fungsi protokol Wi-Fi MAC dan TCP/IP. Anda dapat mengembangkan produk Wi-Fi tertanam sesuai kebutuhan.

Karakteristik dari modul TYWE3S adalah sebagai berikut :

a. Tertanam CPU 32-bit berdaya rendah, yang juga dapat berfungsi sebagai prosesor aplikasi (Laju clock mendukung $80 \mathrm{Mhz}$ dan $160 \mathrm{Mhz}$ ). 
b. Tegangan kerja: 3,0 hingga 3,6 V.

c. Periferal: 9 GPIO, 1 penerima/pemancar asinkron universal (UART), dan konverter analog-ke-digital (ADC).

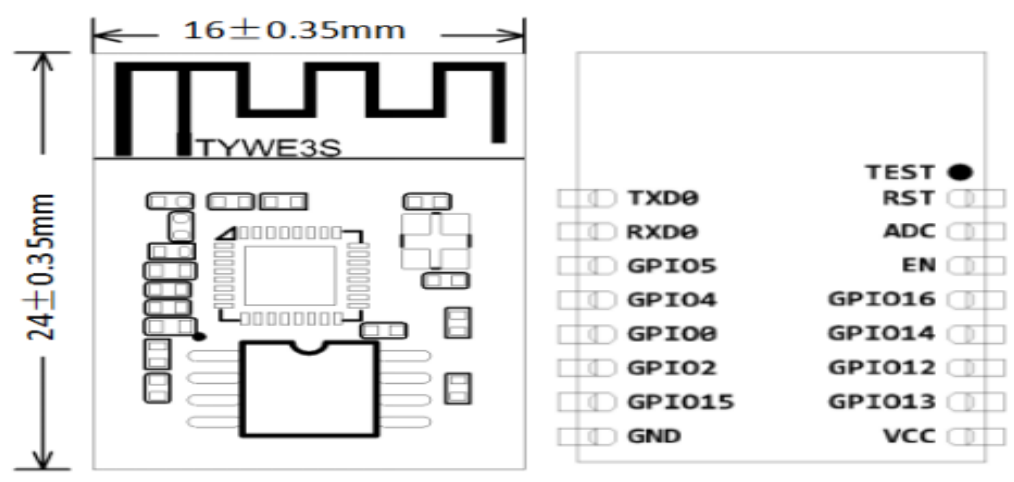

Gambar 6. Modul TYWES

\section{MODEL YANG DIUSULKAN}

\section{A. Blok Diagram Modul Remote Control}

Pada Blok diagram terdapat module inti yaitu WB3S modul yang berbentuk papan PCB yang didalam nya terdapat mikrokontroler inti yaitu TYWE3S sebagai pengontrol dari inti dari semua rangkaian. TYWE3S ini sama halnya dengan Mikrokontroler ESP8266 . IR Receiver Module (IRM) bertugas sebagai penerima input tambahan remote baru jika didalam platform Tuya belum tersedia remote yang di inginkan . Button Module berfungsi untuk mereset remote IR yang jika ingin melakukan koneksi ulang maka perangkat harus di reset melalui push button selama 5 detik. Hasil pemrograman dari WB3S module terdapat output IR Transmit, yang berguna sebagai pemancar infra untuk mengontrol perangkat . LED Module sebagai indicator pada perangkat remote universal IR . Pada inputan terdapat Sub_G Module yang berguna untuk untuk memprogram ulang semua fungsi input dan output. Alat remote control berbasis IoT ini menggunakan inputan menggunakan kabel mikro USB dengan tegangan 5 Volt dan diturunkan menjadi 3 Volt .

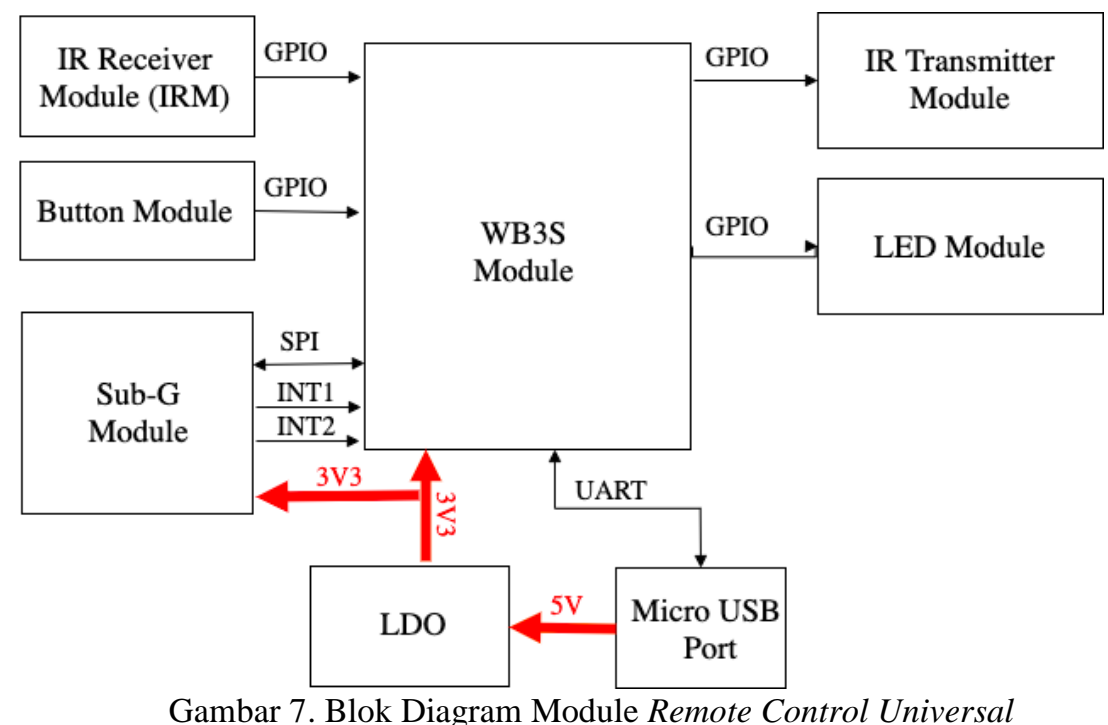

Prosiding Seminar Nasional Sains Teknologi dan Inovasi Indonesia - Akademi Angkatan Udara Volume 3, Tahun 2021: hlm. 157-168 
1. WB3S modul yang berbentuk papan PCB terdiri dari sebuah mikrokontroler inti yaitu TYWE3S sebagai pengontrol semua rangkaian.

2. IR Receiver Module (IRM) berfungsi sebagai penerima input tambahan remote baru jika didalam platform Tuya belum tersedia remote yang di inginkan .

3. Button Module berfungsi untuk mereset remote IR dimana jika ingin meakukan koneksi ulang maka perangkat harus di reset melalui push button selama 5 detik .

4. IR Transmit berfungsi sebagai pemancar infra red untuk mengontrol perangkat .

5. LED Module sebagai indicator pada perangkat remote universal IR .

6. Sub_G Module yang berguna untuk untuk memprogram ulang semua fungsi input dan output.

Alat remote control berbasis IoT yang dibuat menggunakan kabel micro USB dengan tegangan 5 Volt dan di stabilkan menjadi 3 Volt .

\section{B. Perancangan Aplikasi Fitur TUYA}

Aplikasi TUYA akan dirancang pada smartphone untuk mengaktifkan remote control universal yang berfungsi mengontrol beberapa perangkat elektronik dan merancang fitur one push otomatis. Tujuan dari dirancangnya one push otomatis adalah membuat fitur, yang satu tombol sudah akan mengaktifkan langsung beberapa perangkat yang telah disetting pada aplikasi TUYA tersebut.

Pengontrolan perangakat elektronik akan diaplikasikan berdasarkan posisi pengguna yaitu dengan menggunakan GPS sebagai acuannya dan berdasarkan keterangan terbit/tenggelamnya matahari serta cuaca. Semua keadaan tersebut di dapat melalui aplikasi-aplikasi GPS dan weather forecast yang terdapat pada android. .

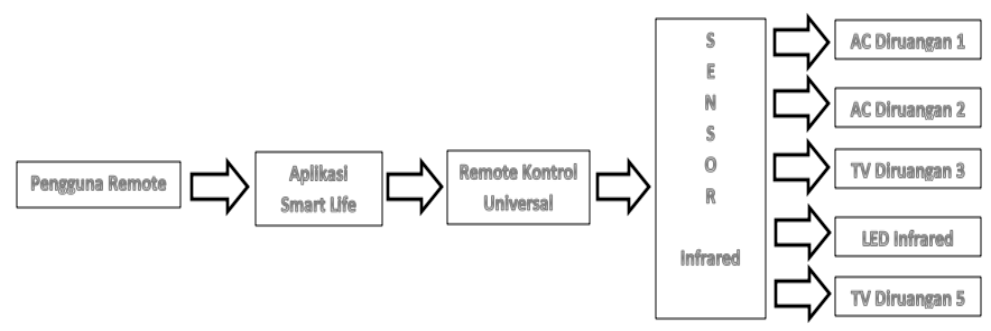

Gambar 8. Diagram Alir Alat

\section{IMPLEMENTASI MODEL DAN PEMBAHASAN}

\section{A. Impelentasi TUYA}

Sistem otomatisasi dan sistem smart pada aplikasi TUYA akan diimplementasikan untuk mengontrol penggunaan AC, televisi. Ketentuan pengontrolan $\mathrm{AC}$ dan televisi dirancang dengan ketentuan sebagai berikut :

1. Air Conditioning dan Televisi akan otomatis Menyala jika pengguna berada di lokasi (Berdasarkan settingan GPS).

2. Air Conditioning dan televisi akan otomatis mati jika pengguna meninggalkan lokasi.

3. Mengganti chanel otomatis sesuai jam tayang pada siaran televisi.

4. Air Conditioning akan menyesuaikan kondisi ruangan berdasarkan suhu di luar ruangan ( Kondisi berdasarkan GPS).

5. Air Conditioning akan menghangatkan ruangan ketika kondisi dingin atau hujan.

6. Air Contioning akan otomatis mati ketika di pagi hari.

Fitur One push Otomatisasi dirancang untuk mengaktifkan perangkat-perangkat tersebut dengan ketentuan-ketentuan : 
1. One push All ON/OFF ( ketika sekali klik pada aplikasi maka Air Conditioning, dan TV akan menyala dan apabila di klik lagi maka Air Conditioning akan mati).

2. One push All ON (Ketika sekali klik maka Air Conditioning dan $T V$,akan nyala).

3. One push All Air OFF (Ketika sekali klik maka Air Conditioning dan TV, akan mati).

4. Delay Some Second For ON /OFF (Ada delai waktu setelah di klik untuk menyalakan dan mematikan perangkat).

Semua otomatisasi yang telah disetting akan berjalan dengan semestinya jika terkoneksi dengan wifi dan jika tidak terkoneksi maka remote tidak akan bekerja. Otomatisasi terhadap GPS akan beroperasi jika GPS pada prangkat smartphone dinyalakan, dan GPS pada smartphone dalam kondisi standby. Pada Otomatisasi waktu berdasarkan waktu yang telah disetting pada smartphone (WIB). Otomatiasasi pada matahari terbit berkerja berdasarkan titik GPS dan waktu lokasi. Jika titik GPS dipindahkan otomatis akan merubah waktu otomatisasi pada matahari terbit Otomatisasi pada cuaca berdasarkan perkiraan cuaca di lokasi pada internet

TABEL I.

PENGATURAN OTOMATISASI ALAT

\begin{tabular}{|c|c|c|c|}
\hline No & $\begin{array}{l}\text { Otomatisasi } \\
\text { Berdasarkan }\end{array}$ & Perangkat & Kondisi \\
\hline \multirow{3}{*}{1} & \multirow{3}{*}{ GPS } & Air Conditioning & $\begin{array}{l}\text { Ketika meninggalkan titik GPS maka TV } \\
\text { mati, Ketika Tiba di Titik GPS maka TV } \\
\text { nyala. }\end{array}$ \\
\hline & & Televisi & $\begin{array}{l}\text { Ketika meninggalkan titik GPS maka AC } \\
\text { mati, Ketika Tiba di Titik GPS maka AC } \\
\text { nyala. }\end{array}$ \\
\hline & & Nakas & - \\
\hline \multirow{3}{*}{2} & \multirow{3}{*}{ Waktu } & Air Conditioning & $\begin{array}{l}\text { Ketika di jam } 22.00 \text { dan pengguna di titik } \\
\text { GPS maka AC nyala di suhu } 25 \text { Celcius. }\end{array}$ \\
\hline & & Televisi & $\begin{array}{l}\text { Ketika masuk jam tayang siaran favorit maka } \\
\text { chanel TV berganti. }\end{array}$ \\
\hline & & Nakas & Ketika di jam 00.00 lampu nakas nyala. \\
\hline \multirow{3}{*}{3} & \multirow{3}{*}{ Matahari Terbit } & Air Conditioning & Ketika matahari terbit maka AC mati. \\
\hline & & Televisi & Ketika matahari terbit maka TV mati \\
\hline & & Nakas & $\begin{array}{l}\text { Ketika matahari terbit maka lampu Nakas } \\
\text { mati. }\end{array}$ \\
\hline \multirow[t]{3}{*}{4} & \multirow[t]{3}{*}{ Cuaca } & Air Conditioning & $\begin{array}{l}\text { Ketika suhu lingkungan diatas } 30 \text { derajat } \\
\text { celcius maka AC setting otomatis menjadi } 16 \\
\text { derajat Celcius. }\end{array}$ \\
\hline & & Televisi & - \\
\hline & & Nakas & - \\
\hline
\end{tabular}

\section{B. Pengujian Konektifitas Remote Control}

Untuk mengetahui jarak maksimum sebenarnya jangkauan alat dapat menggunakan rumus sebagai berikut :

Free Space Path Loss $=$ Tx Power - Tx Cable + Tx Antenna Gain + Rx Antenna Gain- Rx Cable Loss - Rx Sensitivity - Fade Margin

Adapun data-data yang digunakan dalam perhitungan :

- $\quad$ TX Power $=36 \mathrm{dBm}$

- $\quad$ TX Cable Loss $=1 \mathrm{~dB}$ 
- $\quad$ Tx Antenna Gain = 1,5 dBi

- $\quad$ Rx Antena Gain = 24 dBi (Standard Rx antenna WiFi)

- $\quad$ Rx Cable Loss $=1 \mathrm{~dB}$

- $\quad$ Rx Sensitifity $=-68 \mathrm{dBm}$ (Daya pancar untuk mendapatkan $54 \mathrm{Mbps}$ )

- $\quad$ Fade Margin $=0$

- $\quad \mathrm{F}=2,4 \mathrm{GHz}$

Maka FSPL $=36-1+1,5+24-1-68-0$

$$
=-8,5
$$

Distance $=10($ Free Space Path Loss $-92,45-20 \log 10$ (f) $) / 20$

$$
\begin{aligned}
& =10(-8,5-92,45-20 \log 10 \times 2,4) / 20 \\
& =10(-148,95) / 20 \\
& =-29,790 \text { meter }
\end{aligned}
$$

Maka seharusnya jarak yang dapat dijangkau alat untuk terkoneksi WiFi ialah 29,790 meter kondisi tanpa ada penghalang.

Sinyal yang loss di udara untuk beberapa jarak tertera pada tabel 2 berikut ini :

TABEL II.

HASIL FREE SPACE LOSS (DB)

\begin{tabular}{|c|c|}
\hline \hline Jarak $(\mathrm{KM})$ & Free Space Loss $(\mathrm{dB})$ \\
\hline 1 & 99.8 \\
\hline 2 & 105.8 \\
\hline 3 & 109.8 \\
\hline 4 & 112.2 \\
\hline 5 & 114.0 \\
\hline 6 & 115.6 \\
\hline 7 & 116.9 \\
\hline
\end{tabular}

Terlihat pada hasil pengukuran Free Space Loss dengan kenaikan jarak 1 km terdapat 2,285 dB yang hilang .

\section{Hasil Diagnosis Uji Jaringan}

Pengujian terhadap jaringan dimaksudkan untuk mengetahui seberapa kecepatan internet yang terhubung ke remote IR. Pengujian ini dilakukan pada ruang yang terdapat dinding pembatas dan ruang yang tidak terdapat dinidng pembatas. Atas dasar pengujian tersebut, untuk mengatasi keterbatasan karena adanya dinding pembatas, maka digunakan kabel tambahan untuk mengaktifkannya.

TABEL III.

HASIL UJI DIAGNOSIS JARINGAN

\begin{tabular}{|c|c|c|}
\hline \hline $\begin{array}{c}\text { Percobaan } \\
\text { Ke - }\end{array}$ & Jarak & $\begin{array}{c}\text { Kecepatan } \\
\text { Konektifitas }\end{array}$ \\
\hline 1 & 1 meter & $1 \mathrm{~ms}$ \\
\hline 2 & 3 meter & $5 \mathrm{~ms}$ \\
\hline 3 & 5 meter & $10 \mathrm{~ms}$ \\
\hline 4 & 8 meter & $50 \mathrm{~ms}$ \\
\hline 5 & 10 meter & $100 \mathrm{~ms}$ \\
\hline \hline
\end{tabular}


TABEL IV.

HASIL UJI DIAGNOSIS JARINGAN DENGAN DINDING PEMBATAS

\begin{tabular}{|c|c|c|}
\hline \hline $\begin{array}{c}\text { Percobaan } \\
\text { ke - }\end{array}$ & Jarak & $\begin{array}{c}\text { Kecepatan } \\
\text { Konektifitas }\end{array}$ \\
\hline 1 & 1 Meter Pembatas 1 Dinding & $5 \mathrm{~ms}$ \\
\hline 2 & 3 Meter Pembatas 1 Dinding & $15 \mathrm{~ms}$ \\
\hline 3 & 5 Meter Pembatas 1 Dinding & $25 \mathrm{~ms}$ \\
\hline 4 & 1 Meter Pembatas 2 Dinding & $50 \mathrm{~ms}$ \\
\hline 5 & 3 Meter Pembatas 2 Dinding & $150 \mathrm{~ms}$ \\
\hline 6 & 5 Meter Pembatas 2 Dinding & Tidak Terkoneksi \\
\hline \hline
\end{tabular}

Konektifitas pada remote IR tidak memerlukan kecepatan, tetapi memerlukan kestabilan koneksi antara wifi dan remote. Karenanya alat remote IR ini tidak mengkonsumsi banyak kuota untuk digunakan. Terlihat pada tabel nomor 3 ketika jarak 3 meter dan pembatas 2 dinding koneksi sudah mencapa 150 mili Second tetapi alat masih bisa digunakan untuk mengontrol perangkat .

\section{Hasil Pengukuran Waktu Respon Alat}

Dalam proses input dan output data yang dikelola oleh TUYA Cloud maka perlu ada proses untuk menyampaikan informasi/ coding dari remote ke perangkat. Maka ada delay waktu yang diperlukan utuk mengoperasikan alat tersebut, berikut ialah hasil pengukuran delay waktu untuk mengontrol tiap perangkat.

TABEL V.

HASIL PENGUKURAN DELAY WAKTU PADA REMOTE

\begin{tabular}{|c|l|c|}
\hline \hline $\begin{array}{c}\text { Percobaan } \\
\text { ke- }\end{array}$ & \multicolumn{1}{|c|}{ Perangkat } & Delay Proses \\
\hline 1 & Televisi & 5 Second \\
\hline 2 & Air Conditioning & 8 Second \\
\hline 3 & Nakas & 5 Second \\
\hline 4 & All Perangkat On & 10 Second \\
\hline 5 & All Perangkat Off & 10,8 Second \\
\hline
\end{tabular}

Proses waktu delay pada tabel diatas merupakan hal wajar untuk suatu proses download dan upload coding pada TUYA Cloud. Terlihat ketika mengakses 3 perangkat sekaligus maka delay semakin bertambah sampai 10 second.

\section{E. Hasil Uji Kinerja One Push}

Untuk mempermudah pengguna selain mengintegrasikan smart system pada remote dalam perancangan juga menyematkan fitur "One push" di aplikasi, dengan bertujuan memupermudah pengoperasian semua perangkat secara bersamaan. 
TABEL VI.

HASIL SETTING FITUR “ONE PUSH” PADA REMOTE

\begin{tabular}{|c|c|c|c|c|}
\hline $\begin{array}{l}\text { Percobaan } \\
\text { ke- }\end{array}$ & Fitur & Perangkat & $\begin{array}{l}\text { Settingan pada } \\
\text { Remote }\end{array}$ & $\begin{array}{l}\text { Kondisi } \\
\text { Aktual }\end{array}$ \\
\hline \multirow{3}{*}{1} & \multirow{3}{*}{$\begin{array}{l}\text { One push Semua } \\
\text { Perangkat Nyala }\end{array}$} & Air Conditioning & Nyala & Nyala \\
\hline & & Televisi & Nyala & Nyala \\
\hline & & Nakas & Nyala & Nyala \\
\hline \multirow{3}{*}{2} & \multirow{3}{*}{$\begin{array}{l}\text { One push Semua } \\
\text { Perangkat Mati }\end{array}$} & Air Conditioning & Mati & Mati \\
\hline & & Televisi & Mati & Mati \\
\hline & & Nakas & Mati & Mati \\
\hline \multirow{3}{*}{3} & \multirow{3}{*}{$\begin{array}{c}\text { One push Semua } \\
\text { Perangkat Nyala } \\
\text { dengan delay } 5 \text { menit }\end{array}$} & Air Conditioning & Nyala & Nyala \\
\hline & & Televisi & Nyala & Nyala \\
\hline & & Nakas & Nyala & Nyala \\
\hline \multirow{3}{*}{4} & \multirow{3}{*}{$\begin{array}{c}\text { One push Semua } \\
\text { Perangkat mati } \\
\text { dengan delay } 5 \text { menit }\end{array}$} & Air Conditioning & Mati & Mati \\
\hline & & Televisi & Mati & Mati \\
\hline & & Nakas & Mati & Mati \\
\hline
\end{tabular}

\section{F. Hasil Pengukuran Daya}

Pada remote control berbasis IoT ini dirancang menggunakan 6 output tambahan yang dimana setiap output bisa mengontrol tiap ruangan .

TABEL VII.

HASIL PENGUKURAN DAYA TANPA KABEL EXTENSION

\begin{tabular}{|c|c|c|c|c|}
\hline \hline $\begin{array}{c}\text { Percobaan } \\
\text { ke- }\end{array}$ & $\begin{array}{c}\text { Jumlah Output } \\
\text { IR LED }\end{array}$ & Arus & Tegangan & Daya \\
\hline 1 & 1 Output & 1,0 Ampere & 5 Volt & 5 Watt \\
\hline 2 & 2 Output & 1,2 Ampere & 5 Volt & 6 Watt \\
\hline 3 & 3 Output & 1,3 Ampere & 5 Volt & 6,5 Watt \\
\hline 4 & 4 Output & 1,5 Ampere & 5 Volt & 7,5 Watt \\
\hline 5 & 5 Output & 1,8 Ampere & 5 Volt & 9 Watt \\
\hline 6 & 6 Output & 2,1 Ampere & 5 Volt & 10,5 Watt \\
\hline \hline
\end{tabular}

Pada hasil pengukuran tiap output didapati ketika semua output digunakan kurang lebih mengkonsumsi daya 10 Watt dan jika dalam keadaan standby yang hanya menggunkan daya untuk menangkap sinyal wifi saja hanya menggunakan daya 5 Watt.

TABEL VIII.

HASIL PENGUKURAN DAYA DENGAN KABEL EXTENSION

\begin{tabular}{|c|c|c|c|c|c|}
\hline \hline $\begin{array}{c}\text { Percobaan } \\
\text { Ke- }\end{array}$ & $\begin{array}{c}\text { Jumlah Output IR } \\
\text { LED }\end{array}$ & $\begin{array}{c}\text { Panjang } \\
\text { Extension }\end{array}$ & Arus & Tegangan & Daya \\
\hline 1 & OUTPUT 1 & 5 Meter & $1,5 \mathrm{~A}$ & 5 Volt & 7,5 Watt \\
\hline 2 & OUTPUT 2 & 7 Meter & $1,7 \mathrm{~A}$ & 5 Volt & 8,5 Watt \\
\hline 3 & OUTPUT 3 & 5 Meter & $1,6 \mathrm{~A}$ & 5 Volt & 8 Watt \\
\hline 4 & OUTPUT 4 & 7 Meter & $1,7 \mathrm{~A}$ & 5 Volt & 8,5 Watt \\
\hline 5 & OUTPUT 5 & 5 Meter & $1,6 \mathrm{~A}$ & 5 Volt & 8 Watt \\
6 & OUTPUT 6 & 7 Meter & $1,7 \mathrm{~A}$ & 5 Volt & 8,5 Watt \\
\hline \hline
\end{tabular}


Untuk mengontrol beberapa ruangan maka diperlukan 2 buah kabel tunggal yang panjang sebagai penghubung ke LED IR. Maka dari itu didapati jika semua port terhubung dan digunakan secara bersamaan maka bisa mengkonsumsi daya sekitar 49 Watt .

\section{KESIMPULAN}

Perancangan remote control universial ini dapat menjangkau jarak untuk terkoneksi dengan wifi sejauh 27,79 meter dalam kondisi tanpa penghalang dengan free space Loss setiap kenaikan $1 \mathrm{~km}$ sebesar 2,285 dB.

Waktu delay remote ketika menggunaka one push 10 detik. Untuk konsumsi daya ketika ketika mengaktifkan seluruh perangkat apabila menggunakan wifi sebesar 44,5 Watt ini lebih rendah dibandingkan apabila menggunakan kabel extention yaitu sebesar 49 Watt.

Kelanjutan dari penelitian remote control universal ini diharapkan dapat diaplikasikan dengan menggunakan perangkat yang lebih banyak dan faktor-faktor penghalang dapat diminimalisasi dengan memperhatikan faktor jaringan dan jenis remote control tersebut.

\section{UCAPAN TERIMA KASIH}

Ucapan terima kasih atas terbitnya naskah ini pada Seminar Nasional Sains Teknologi dan Inovasi Indonesia 2021 sebagai bagian kolaborasi / kerja sama dalam publikasi hasil penelitian antara Universitas Dirgantara Marsekal Suryadarma dengan Akademi Angkatan Udara.

\section{REFERENSI}

[1] Buyya, Rajkumar dan Amir Vahid Dasjerdi. 2016. Internet Of Things: principles and paradigms, Melbourne: Elsevier.

[2] Behmann, Fawzi dan Kwok wu. 2015. Collaborative Internet Of Things (C-IoT): for future smart connected life and business, Texas:John Wiley \& Sons.

[3] Ardiansyah, dkk. Internet Of Things (Iot): Sistem Kendali Jarak Jauh Berbasis Arduino Dan Modul Wifi ESP8266, Prosiding Seminar Nasional XII "Rekayasa Teknologi Industri dan Informasi, 2017.

[4] Evandi, Nathan Rizqi, dkk. Rancang Bangun Aplikasi IoT Remote Tv Berbasis Realtime Databese dan Komunikasi Inframerah, Seminar Nasional Teknik Elektro, 2019

[5] Yusika, Andi, dkk. Perancang Mobile Remote control menggunakan kontrol Bluetooth Arduino Uno, Sebatik 1410-3737.

[6] Ramadan, Dadan Nur, dkk. Perancang Dan Realisasi Mobile Remote control Menggunakan Firebase, Jurnal Elektro Telekomunikasi Terapan, 2017.

[7] Pribadi, Octara. Sistem Kendali Jarak Jauh Air Conditioner (AC) Berbasis IoT, Jurnal Times, Volume 9 Nomor 1, 2020.

[8] Ali, Al-Sabri Akram, dan Xianan Bao. Design and Research Of Infrared Remote control Based On ESP8266, Open Acces Livrary Journal, Volume 8, 2021.

[9] https://www.amazine.co/14859/cara-kerja-remote-control-ketahui-2-jenis-remote-control/ Diakses pada 8 Mei 2021.

[10] A. Infantono and M. Liandana, "Desain Sistem Teknologi Embedded-RFID Untuk Tiket Penumpang Pesawat Komersil di Bandara Jajaran PT. Angkasa Pura", AAU-JDST, vol. 4, no. 2, pp. 107-118, Dec. 2020. 